\title{
Experience of using Skeletal Anchorage System for Orthodontics treatment
}

Manabu Habu', Kazuhiro Tominaga ${ }^{1}$, Michi Fujita', Izumi Yoshioka ${ }^{1}$, Jinichi Fukuda ${ }^{1}$ and Junichiro Nagayama ${ }^{2}$ ( ${ }^{1}$ First Department of Oral Surgery, Kyushu Dental College and ${ }^{2}$ Nagayama Orthodontic Clinic)

We investigated 22 patients who were implanted the plate of Skeletal Anchorage System (SAS). SAS was mostly used for the distalization and intrusion of the molar. According to the case, anterior open bite case was mostly selected. The accepted complications were the infection of the implanted site which was $32.1 \%$. But the development of these infection with dental prophylaxis was not relevant. It is necessary to examine further the method of administration and use of SAS over the long period of time.

\section{9、顎関節 joint effusion の検出における脂肪抑制 MR 画像の有用性}

○田中 達朗·森本 泰宏·鬼頭 慎司·岡部 幸子·篠原 雄二·大庭 健 九歯大 ·歯放

本研究では，顎関節 joint effusionの検出における脂肪抑制 MR 画像の有用性について評俩した，対象は顎関節部 の痛みを主訴として来院し, MRI 検査を施行した 200 症例 (400顎関節) である. MRI 検查は顎関節部に対する通常 の撮像に加え, fat saturation法による脂肪抑制画像をむ施行し, それぞれの撮像法により検出されたjoint effusionの検出率および疼痛との相関性について分析した。結果としては, 疼痛のある顎関節においては, 通常の T2WI に比べ脂肪抑制 T2WIによる検出率は有意に高かった。また，いずれの撮像法においても joint effusion と疼 痛との相関性は認められたが，脂肪抑制 MR 画像の方が通常の T2WIに比べ有意に高い相関性を示した。

Utility of frequency-selective fat saturation MR images for the detection of joint effusion in the temporomandibular joint

Tatsurou Tanaka, Yasuhiro Morimoto, Shinji Kito, Sachiko Okabe, Yuji Shinohara and Takeshi Ohba (Department of Dental Radiology, Kyushu Dental College)

The purpose of this study was to evaluate the utility of frequency-selective fat saturation MR images for the detection of joint effusion in the temporomandibular joint (TMJ). TMJ effusion was sought on FS T2-weighted images and conventional T2-weighted images in 400 joints obtained from 200 patients with TMJ-related pain. The relationship between the pain and TMJ effusion, which was judged by FS-sequences or conventional sequences, was analyzed. The detection rate of TMJ effusion by FS-sequences was significantly greater than by conventional methods, and the results showed a significant relationship between the MRI interpretation of TMJ effusion, using FS-sequences or conventional methods, and the presence of pain. The correlation between TMJ effusion on FS-sequences and the pain was significant than the conventional method.

\section{0. 九州歯科大学附属病院第 1 義歯科における高齢患者の動向}

○尾座本まゆみ·松木 貴彦·中村 恵子·鱒見 進一 九歯大·補綴 1

わが国の高齢者人口は年々増加傾向にあり，さまざまな問題がクローズアップされ，国や地方自治体は介護保険法 の施行などの対策を講じている，この様な状況下で高齢者の受診率が高い当科においても，高齢患者の詳細について 把握しておく必要があると考えられる，今回，2002 年度に新患として第 1 義歯科を受診した患者を対象に調査を行っ た. 対象患者数 330 名のうち，65歳以上の高嚙患者は 119 名で全体の $36.1 \%$ を占めていた。さらに高齢患者について 各々の地域, 全身疾患の有無や種類, 紹介元, 当科での処置内容などについて調査を行い検討した。地域別では北九 州市が 98 名 (82.4\%) と非常に高率を占めていた。また何らかの全身疾患を有するものは 119 名のうち 73 名で，有 病率は $61.3 \%$ であた，今回の調査では現状分析であったが，今後も継続して調查を行うことにより，患者の動向を 
詳細に把握し，高齢者診療の実態をより明確にしたいと考えている.

\title{
Survey of the elderly patients in The First Department of Prosthetic Dentistry
}

Mayumi Ozamoto, Takahiko Matsuki, Keiko Nakamura and Shin-ichi Masumi (Department of Removable Prosthodontics, Kyushu Dental College)

There is an yearly tendency of increase in the senior citizen population of our country. Regarding this condition, to grasp in details of the elderly patients is very important. We surveyed the new out patients who visited our clinic from April, 2002 to March, 2003. The elderly patients of 65 years old or more were 119 in 330 outpatients (36.1\%). In the residential area of these patients, Kitakyushu city, the number was $98(82.4 \%)$. The patients with some systemic disease were $73(61.3 \%)$. We will continue this survey and hope to grasp in details of the elderly patients.

\section{1. 糖尿病患者における歯周病治療の過酸化脂質改善効果}

○園木 一男 ${ }^{1} \cdot$ 中島左代里 $^{2} \cdot$ 内藤 徹 ${ }^{2} \cdot$ 高田 豊 $^{1} \cdot$ 横田 誠 $^{2}$ 1 九歯大 $\cdot$ 内科, ${ }^{2}$ 九歯大 $\cdot$ 保存 2

糖尿病患者は，酸化ストレスのため動脈硬化を起こしやすい，歯周病は心血管疾患の危険因子である，そこで，歯 周病を持つ糖尿病患者 5 名（年齢 49.2 歳, 男性 4 名, 女性 1 名）之非糖尿病患者 6 名（年齢 60.4 歳, 男性 2 名, 女性 4 名）に歯周病治療を行い, 治療の前後で血糖, 脂質および酸化ストレスの变化を検討した。治療後, 歯周ポケット, 出血指数は両群とも有意に減少した。柬周病治療は糖尿病群の血糖コントロールや脂質に影響しなかったが，糖尿病 群で過酸化脂質を改善し, 雨群で抗 MDA-LDL 抗体を有意に低下させた。糖尿病患者は歯周病の合併によりさらに 酸化ストレスを受けているが，歯周病治療により酸化ストレスが改善されることが示唆された。

\section{Improvement of lipid peroxide by periodontal treatment in diabetic patients}

Kazuo Sonoki ${ }^{1}$, Sayori Nakashima ${ }^{2}$, Toru Naito ${ }^{2}$, Yutaka Takata ${ }^{1}$ and Makoto Yokota ${ }^{2}{ }^{1}$ Department of $^{2}$ Internal Medicine and ${ }^{2}$ Department of Periodontology and Endodontology, Kyushu Dental College)

To investigate the role of periodontal disease on atherosclerosis, we assessed the effects of periodontal treatment on lipid peroxide (LPO) in diabetic patients comparing with non-diabetic patients. Five diabetic patients (age 49.2 years-old, male 4, female 1) and six non-diabetic patients (age 60.4 years-old, male 2, female 4) were given periodontal treatment. After the treatment, periodontal pocket depth and bleeding on probing were improved in both groups. LPO in diabetic group and anti-MDA-LDL antibody in both groups were significantly decreased. Periodontal treatment is useful to improve oxidative stress and expected to prevent the atherosclerosis in diabetes mellitus.

12. Actinobacillus actinomycetemcomitans 由来の Cytolethal distending toxin B 単独投与による細胞致死活 性の発現

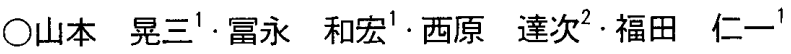

${ }^{1}$ 九歯大· 口外 $1,{ }^{2}$ 九歯大·微生物

Cytolethal distending toxin (CDT) は, 様々な細菌より産生される holotoxin であり, 宿主細胞に G2 期での

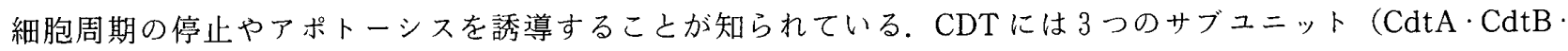
$\mathrm{CdtC})$ が存在し，それぞれが毒素活性に必要であるが，DNase 活性を持っ CdtBが活性本体であると考えられてい る。今回我々は，癌細胞へ $\mathrm{CdtB}$ の単独投与を試み，その毒素活性を観察した，A. actinomycetemcomitans 由来 $\mathrm{CdtB}$ で形質転換したE.coli リコンビナントタンパクを発現させ，CdtB タンパクを精製した．次に，BioPORTER ${ }^{\mathrm{TM}}$ を用い，ヒト歯肉扁平上皮癌 cell line Ca9-22 に CdtB を導入し, MTT assay, F1ow cytometry, hoechst 染色 で評価した. CdtA と CdtC の存在しない CdtB 単独投与であ G2 期での細胞周期の停止は認められたが,アポトーシ スの所見を示した細胞はわずかであった。

Cytolethal distending toxin B from Actinobacillus actinomycetemcomitans induces cell death. 